\title{
IMPACT OF TQM PRACTICES ON INNOVATION PERFORMANCE AMONG MANUFACTURING COMPANIES IN MALAYSIA
}

\author{
C.S. Long ${ }^{1^{*}}$, M.H. Abdul Aziz ${ }^{2}$, T.O.Kowang ${ }^{3}$ \& W.K.W. Ismail ${ }^{4}$ \\ 1, 2, ${ }^{3}$ Department of Management \\ Universiti Teknologi Malaysia, Malaysia \\ ${ }^{1}$ slchoi@utm.my, ${ }^{2}$ mhamizan7@live.utm.my, ${ }^{3}$ oktan@utm.my \\ ${ }^{4}$ International Business School \\ Universiti Teknologi Malaysia, Malaysia \\ mwkhair@ibs.utm.my
}

\begin{abstract}
This study examines the impact of total quality management (TQM) practices on an organisation's innovation performance. Correlation coefficient and regression analysis is used to examine the relationship between TQM practices and innovation performance. This study's sample is drawn from the manufacturing organisations located in the district of Rawang in the state of Selangor, Malaysia. The empirical results of this study confirm that TQM has a positive impact on innovation performance across five measured practices: customer focus, leadership, process management, strategic planning, and people management. Furthermore, the three most influential TQM practices are identfied as people management, process management, and customer focus. Managers in the manufacturing sector can find this study useful, especially if they are aiming to improve their organisation's innovation performance with the help of quality management practices.
\end{abstract}

\section{OPSOMMING}

Die impak van algehele gehaltebeheer op ' $n$ organisasie se innovasievertoning word ondersoek. Korrelasiekoëffisiënt- en regressie analise word gebruik om die verhouding tussen algehele gehaltebeheer en innovasievertoning te ondersoek. Die steekproef is uit vervaardigingsorganisasies in die Rawang streek van Selangor, Maleisië geneem. Die empiriese resultate dui daarop dat algehele gehaltebeheer ' $n$ positiewe invloed op die innovasievertoning van vyf gemete praktyke het, naamlik kliëntefokus, leierskap, prosesbeheer, strategiese beplanning en menslikehulpbronbestuur. Verder word menslikehulpbronbestuur, prosesbeheer en kliëntefokus as die drie invloedrykste algehele gehaltebeheer praktyke identifiseer. Bestuurders in die vervaardigingsektor mag hierdie resultaat nuttig vind, veral as hulle mik om hul organisasie se innovasievertoning te verbeter met die hulp van gehaltebeheer praktyke. 
This study investigates the relationship between total quality management (TQM) practices and the innovation performance of an organisation. In particular, this study considers the impact that particular elements have on innovation performance, since evidence on the linkage between these variables is insufficient $[1,2]$. Prajogo and Sohal $[3,4]$ have stressed in their work that positive correlations exist between TQM and innovation performance.

This study is motivated by the need to examine the innovation performance of the manufacturing industry in Malaysia by focusing on the use of TQM practices. Malaysia has become one of the fastest growing developing countries, with significant growth rates recorded in the manufacturing sector over the last few decades. Based on information from the Malaysian Department of Statistics [5], the manufacturing industry now contributes approximately 40 per cent to Malaysia's gross domestic product (GDP). The manufacturing output has had an average annual increase of 12.9 per cent. In this regard, the study of the relationship between TQM and innovation performance is important because it provides a theoretically supported platform for the manufacturing industry in Malaysia to achieve greater outcomes. Therefore, this study aims to examine whether the application of TQM practices enables organisations to build their competence and competitiveness through innovation.

A few Malaysian researchers have revealed that strategic planning, customer focus, analysis of information, leadership, human resource management, and process management are associated positively with product innovation performance. Analysis of information is seen as an important TQM practice for improving a firm's innovation performance. Organisations can focus their efforts on these TQM practices in order to gain product innovation in a competitive environment [6]. However, the results are inconsistent, and are unable to tell us whether TQM practices are always related positively to innovation performance, particularly for organisations in Malaysia.

According to Hovgaard and Hansen [7], there are multiple definitions and perspectives of quality. Early research in this field examined primarily the concept of 'quality' from the aspect of 'conformance to specifications'. Such a view is flawed, however, because it fails to address the multi-dimensional nature of quality and the idea that 'conformance to specification' is only one of the key dimensions. Other key dimensions include reliability, durability, and customer satisfaction. For studies on the impact of quality on organisational performance, there are numerous possible dimensions that can be explored. In today's business environment, many researchers have argued that innovation must be added to the growing list of essential organisational performance metrics. However, as pointed out by Prajogo and Sohal [4], the empirical studies that support the relationship between TQM and innovation are still inconclusive.

Based on the study by Cormican and O'Sullivan [8], many organisations are unsuccessful in managing organisational innovation well. This is caused mainly by organisational innovation research that has not been done in a convincing and consistent manner with acceptable and reliable explanations. Consequently, ideas that could bring practical transformation cannot be captured and understood critically [9]. In addition, Chong and Rundus [10] and Leavengood [2] have also stressed that there is a lack of research that looks in-depth at the possible linkages between TQM practices and organisational performance. Within this context, organisational performance is taken as being equivalent to innovation performance. As made clear by Terziovski and Samson's work [11], innovation is representative of an organisation's performance when the number of new products produced are measured and when new processes are created to make work more efficient.

With the above-mentioned arguments, it is clear that a study of the relationship between 
TQM and innovation performance is necessary. Such a study needs to provide a theoretical yet practical platform to service and manufacturing organisations so that sustainable competitive advantages can be gained. As such, the research objectives of this study are:

1. to explore the relationship between TQM practices and innovation; and

2. to identify the TQM practices that have contributed significantly to innovation.

This study will meet these research objectives by using a quantitative methodology. This research seeks to confirm whether all TQM practices chosen in this study are positively related to innovation performance.

\section{PREVIOUS STUDIES ON THE RELATIONSHIP BETWEEN TQM PRACTICES AND INNOVATION PERFORMANCE}

Studies of the relationship between quality and innovation are more recent and less extensive that those conducted on the relationship between quality and other measures of organisational performance. Moreover, the conclusions of such studies are often inconsistent. Although they different in some respects, both TQM and innovation share some similarities. For instance, the element of continuous improvement is the key feature of both TQM and innovation, as well as the element of an open culture. This indicates that an organisation that has TQM practices can be more innovative than organisations that do not implement such practices. In this regard, TQM is also a vehicle for organisations to become innovative. In short, TQM leads to innovation [1]. The nature of the relationship between TQM and innovation performance is still a much-debated issue; some researchers state that the relationship is positive while others indicate otherwise.

Researchers who support the notion that the relationship is positive have identified customer satisfaction as one of the core elements of TQM practices because it creates the momentum for organisations to be more innovative in developing and launching new products or creating new services [12]. Perdomo-Ortiz et al. [13] also support the argument that TQM favours the innovative capability of development. Prajogo and Sohal [14] conducted their study on managers from manufacturing and non-manufacturing companies in Australia. They was found that TQM had an impact on both product quality and product innovation performance, although the former had a stronger relationship with TQM. In addition, Pinho [15] revealed that the performance of small-to-medium enterprises (SMEs) is relevant to the practices of TQM. Some of the practices found to be critical for SMEs are leadership support, managerial training, customer focus, and a systematic process of quality assurance.

Pekovic and Galia's [16] study has also concluded that TQM improves innovation performance, putting specific emphasis on the contribution of dimensions to create an environment and culture that supports innovation. Moreover, quality systems improve innovation in dimensions such as customer orientation, employee involvement, human resources management, leadership, access to tools, meeting frequency, motivation, and team spirit. Santos-Vijande and Alvarez-Gonzalez [17] have also confirmed that TQM strongly influences technical and administrative innovation, regardless of turbulence in the market in which the organisation operates. As pointed out by these authors, the implementation of TQM in terms of people management and actively involving employees in organisational management may influence the company's basic mission and vision as it relates to their innovation performance. Furthermore, a similar study by Abrunhosa and Moura [18] on the footwear industry in Portugal has also discovered that TQM philosophies such as communication, supportive people management practices, and teamwork relate positively to the adoption of technological innovation. TQM practices will never be successful if employees fail to understand their purpose and meaning. Employees need to be reminded and pushed constantly to achieve the organisation's goals. The study of Ooi et al. [19] , which was based on managers working in manufacturing organisations in Malaysia, confirmed that innovation performance is closely linked with several TQM practices such as people management, process management, customer focus, and strategic planning. Cemal 
et al. [20] conducted a questionnaire survey with 261 middle and upper level managers of 104 manufacturing, information technology, and service companies of varying sizes in Turkey. Their conclusions from this study corresponded with the conclusions of Ooi et al. [19] in Malaysia.

On the contrary, researchers who support the idea that TQM is correlated negatively with innovation [21] argue that customer focus is related significantly to product conformance or quality, and not to the latest or most innovative product. This negative correlation has been supported by Kim and Marbougne [22], Slater and Narver [23], and Wind and Mahajan [24]. Singh and Smith [1] have also concluded from their survey, conducted on 418 manufacturing organisations in Australia, that a negative relationship exists between TQM and innovation performance. This type of finding further complicates the implementation of TQM practices; and these contradictory results highlight the need for further examination of the linkage of the two variables. Such a negatively correlated perspective does not completely reject the idea that TQM may support and facilitate innovation to a certain extent; the failure of TQM may occur due to imperfection in carrying out practices at all levels of employees in the organisation.

\section{CONCEPTUAL FRAMEWORK}

The conceptual framework of this study (see Figure 1) is based on the literature review above. This framework shows that TQM practices that serve as independent variables have a direct impact on the dependent variables, which are drawn from the innovation performance.

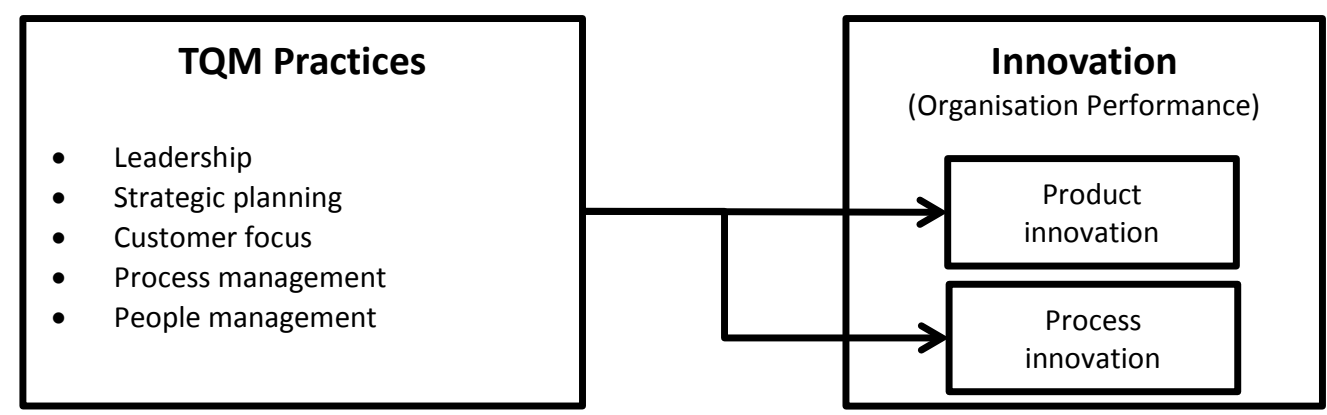

Figure 1: Conceptual framework

\section{RESEARCH METHOD}

This study has adopted a quantitative approach. Questionnaires were distributed to 123 respondents (executive level and above) from 35 small- and medium-sized manufacturing organisations in Malaysia, in order to gauge two major measures: TQM and innovation. The organisations are ISO-certified, and are located in the district of Rawang, Selangor, in Malaysia. They were selected randomly from the 2010 directory of the Federation of Malaysian Manufacturers in Selangor. The questionnaire, which followed that developed by Leavengood [2], consisted of 36 questions in seven different sections. The first five sections focused on TQM practices: leadership, strategic management, customer focus, process management, and people management. The remaining two sections focused on the measurement of innovation performance: product innovation and process innovation. 


\subsection{Pilot test}

Pilot testing gauges the reliability of the measuring instrument, particularly in terms of the clarity of a questionnaire's content, so that the respondents' understanding is on a par with the intended meaning, in order to truly reflect their opinions. As such, the questionnaire was checked and edited to eliminate ambiguity before it was distributed for pilot testing to ten managerial level workers in manufacturing organisations. After the data collection for the pilot study had been completed, the reliability of the measurement scales were examined.

Table 1: Reliability test

\begin{tabular}{ll}
\hline Variables & Cronbach's Alpha \\
\hline Leadership & 0.897 \\
Strategic planning & 0.785 \\
Customer focus & 0.736 \\
Process management & 0.812 \\
People management & 0.898 \\
Product innovation & 0.895 \\
Process innovation & 0.647 \\
\hline
\end{tabular}

The results of the Cronbach's alpha for the TQM and innovation performance variables are shown in Table 1.

The Cronbach's alpha value is accepted once it exceeds 0.70 . However, in some exploratory research, this may be decreased to 0.60 [25]. In this study, the Cronbach's alpha values have generally shown that the measurement scales are reliable.

\section{FINDINGS}

\subsection{Demographic information of respondents}

The response rate of this survey was 67.5 per cent. That means that out of 123 distributed questionnaires, only 83 were completed. Below is the demographic information of the respondents (Table 2 ).

Table 2: Demographic Information of respondents

\begin{tabular}{|c|c|c|}
\hline Gender & Frequency & $\%$ \\
\hline Male & 52 & 62.7 \\
\hline Female & 31 & 37.3 \\
\hline Total & 83 & 100 \\
\hline Education level & Frequency & $\%$ \\
\hline Doctor of Philosophy & 1 & 1.2 \\
\hline Master's Degree & 10 & 12 \\
\hline First Degree/Equivalent & 61 & 73.5 \\
\hline Others & 11 & 13.3 \\
\hline Total & 83 & 100 \\
\hline Age & Frequency & $\%$ \\
\hline Less than 30 years old & 34 & 41 \\
\hline 30 to 40 years old & 39 & 47 \\
\hline 41 to 50 years old & 10 & 12 \\
\hline 50 years old and above & 0 & 0 \\
\hline Total & 83 & 100 \\
\hline Experience & Frequency & $\%$ \\
\hline Less than 5 years & 28 & 33.7 \\
\hline 5 to 15 years & 41 & 49.4 \\
\hline 16 to 25 years & 13 & 15.7 \\
\hline 26 years and above & 1 & 1.2 \\
\hline Total & 83 & 100 \\
\hline
\end{tabular}




\subsection{Normality test}

An assessment of the normality of data is required for many statistical tests because a normal dataset is an underlying assumption in parametric testing. For this purpose, data screening and transformation techniques are useful techniques for making sure that the data have been entered correctly and that the distributions of the variables are normal. If not, this may affect the validity of the results produced thereafter [26]. For this research, the normality testing results are shown in Table 3.

Table 3: Normality test

\begin{tabular}{lll}
\hline Variables & Skewness & Kurtosis \\
\hline Leadership & -0.788 & -0.497 \\
Strategic planning & -1.295 & -1.377 \\
Customer focus & -1.208 & -0.853 \\
Process management & -1.481 & -0.333 \\
People management & -0.818 & -0.929 \\
\hline
\end{tabular}

If the skewness and kurtosis values are between -1.96 and +1.96 , it is assumed that the distribution is symmetrical. Although this does not necessarily indicate that the distribution is normal, it is a necessary condition for normality [26].

\subsection{Factor analysis}

Factor analysis is used as an exploratory technique when the researcher wishes to summarise the structure of a set of variables. On the other hand, confirmatory factor analysis (CFA) is appropriate for testing a theory about the structure of a particular domain [26]. In this study, CFA was done using SPSS. The results are shown in Table 4. Based on the study by Hoang et al. [12], the validity of each variable was examined using CFA, in order to eliminate items with weak loading coefficients (i.e., less than 0.5 ).

Table 4: Results of the factor analysis

\begin{tabular}{|c|c|c|}
\hline Factors & Items & Factor loading \\
\hline \multirow[t]{5}{*}{ Leadership } & Q1 & 0.508 \\
\hline & Q2 & 0.708 \\
\hline & Q3 & 0.811 \\
\hline & Q4 & 0.820 \\
\hline & Q5 & 0.481 \\
\hline \multirow[t]{4}{*}{ Strategic planning } & Q6 & 0.614 \\
\hline & Q7 & 0.780 \\
\hline & Q8 & 0.677 \\
\hline & Q9 & 0.786 \\
\hline \multirow[t]{6}{*}{ Customer focus } & Q10 & 0.606 \\
\hline & Q11 & 0.549 \\
\hline & Q12 & 0.625 \\
\hline & Q13 & 0.717 \\
\hline & Q14 & 0.418 \\
\hline & Q15 & 0.618 \\
\hline Process & Q16 & 0.639 \\
\hline \multirow[t]{5}{*}{ management } & Q17 & 0.562 \\
\hline & Q18 & 0.554 \\
\hline & Q19 & 0.475 \\
\hline & Q20 & 0.677 \\
\hline & Q21 & 0.455 \\
\hline People & Q22 & 0.625 \\
\hline \multirow[t]{4}{*}{ management } & Q23 & 0.563 \\
\hline & Q24 & 0.842 \\
\hline & Q25 & 0.821 \\
\hline & Q26 & 0.580 \\
\hline \multirow[t]{3}{*}{ Product innovation } & Q27 & 0.702 \\
\hline & Q28 & 0.572 \\
\hline & Q29 & 0.803 \\
\hline
\end{tabular}




\begin{tabular}{lll}
\hline & Q30 & 0.840 \\
Process innovation & Q31 & 0.792 \\
& Q32 & 0.588 \\
& Q33 & 0.807 \\
& Q34 & 0.695 \\
& Q35 & 0.636 \\
& Q36 & 0.704 \\
\hline
\end{tabular}

Even though the factor loading for Questions 5, 14, 19, and 21 are less than 0.5 , these questions are important for measuring the variables related to innovation performance, as indicated by Leavengood [2]. Also, according to Hair et al. [25], the loading is said to have met the minimum requirement when it is greater than 0.3 . So these questions were retained.

\subsection{Correlational and multiple regression analysis}

Table 5 shows the results of the relationship between TQM practices and innovation performance. As clearly indicated in the table, all TQM practices are correlated significantly and positively with innovation performance.

Table 6 shows the results of the regression analysis that was conducted to find out which TQM practices have contributed significantly to innovation performance. The most important information here is the values of R-square or the adjusted R-square, because they represent the amount or percentage of variance explained collectively by the TQM practices concerning innovation performance. In this study, the values of R-square were 75.8 per cent; this indicates that the model is quite good in predicting innovation performance. The beta coefficients in the regression results were interpreted similarly to the results of correlation coefficients. The value of the beta coefficient shows the contribution of independent variables to dependent variables, which can be justified by looking at the significance level of the T-test result. The highest beta value of the standardised coefficient shows that people management contributes significantly to innovation performance $(B=.441 ; p<0.05)$. Other significant variables include customer focus $(B=.255 ; p<0.05)$ and process management $(B=.247 ; p<0.05)$.

Prior to regression analysis, a multiple variable multicollinearity test was performed to gauge the tolerance value and the variance inflation (VIF). A tolerance of less than 0.20 or 0.10 , and/or a VIF of 5 or 10 and above, indicates a multicollinearity problem [27]. The result of the multicollinearity test for this study showed that the tolerance value was higher than 0.10 and the VIF was below 10. There is thus no multicollinearity problem in this study, meaning that the result from the regression analysis is acceptable.

Table 5: Pearson $r$ analysis

\begin{tabular}{llc}
\multicolumn{1}{c}{ Variable } & \multicolumn{2}{c}{ Innovation performance } \\
\cline { 2 - 3 } & $r$ & Sig. \\
\cline { 2 - 3 } Leadership & $.591^{* *}$ & .000 \\
Strategic planning & $.675^{* *}$ & .000 \\
Customer focus & $.808^{* *}$ & .000 \\
Process management & $.780^{* *}$ & .000 \\
People management & $.802^{* *}$ & .000 \\
Overall & $.831^{* *}$ & .000 \\
\hline
\end{tabular}

** Sig. $<0.01$ (two-tailed)

\section{DISCUSSION AND CONCLUSION}

The discussion will focus on the two research objectives.

Objective 1: The relationship between TQM practices and innovation performance The relationship between total quality management practices and innovation performance is important if manufacturing organisations are to compete and gain competitive 
advantage. In addition, it helps the organisation to be more innovative and to identify which TQM practices can significantly improve their innovation performance.

The strength and direction of this relationship was gauged using Pearson's correlation coefficient. The findings of this study showed that TQM practices are correlated positively and significantly with innovation performance. From the data collected, TQM practices contribute 83.1 per cent to both product and process innovation. This result is similar to that of Lee et al. [6], which also showed that TQM practices such as leadership, strategic planning, customer focus, information and analysis, human resource management, and

Table 6 : Regression analysis

\begin{tabular}{|c|c|c|c|c|c|c|c|}
\hline Model & $\mathbf{R}$ & \multicolumn{2}{|c|}{ R-square } & $\begin{array}{l}\text { Adjusted } \\
\text { R-square }\end{array}$ & \multicolumn{3}{|c|}{$\begin{array}{l}\text { Std. error of } \\
\text { the estimate }\end{array}$} \\
\hline 1 & $.871^{\mathrm{a}}$ & \multicolumn{2}{|c|}{.758} & .742 & \multicolumn{3}{|c|}{.327} \\
\hline \multicolumn{8}{|c|}{ Coefficients $^{\mathrm{d}}$} \\
\hline \multirow{2}{*}{ Model } & \multicolumn{2}{|c|}{$\begin{array}{l}\text { Unstandardised } \\
\text { coefficients }\end{array}$} & $\begin{array}{c}\text { Standardised } \\
\text { coefficients }\end{array}$ & \multirow{2}{*}{$\mathrm{t}$} & \multirow{2}{*}{ Sig. } & \multicolumn{2}{|c|}{$\begin{array}{c}\text { Collinearity } \\
\text { statistics }\end{array}$} \\
\hline & B & Std. error & Beta & & & Tolerance & VIF \\
\hline (constant) & .198 & .255 & & .777 & .439 & & \\
\hline Leadership & -.114 & .087 & -.120 & -1.322 & .190 & .382 & 2.616 \\
\hline Strategic planning & .104 & .098 & .114 & 1.159 & .250 & .325 & 3.073 \\
\hline Customer focus & .273 & .142 & .255 & 1.914 & .050 & .178 & 5.632 \\
\hline Process management & .256 & .119 & .247 & 2.156 & .034 & .240 & 4.166 \\
\hline People management & .392 & .081 & .441 & 4.858 & .000 & .381 & 2.626 \\
\hline
\end{tabular}

process management are positively significant for innovation. Other studies that showed identical results include those of Hoang et al. [12] and Prajogo and Sohal [14].

Besides those findings, collaboration between all supply chain companies is important to ensure that the supplied products meet the established standard of quality. As such, TQM practices act as a stepping-stone to producing more competitive and innovative organisations that optimise resources and effectively reduce operational costs.

Objective 2: TQM practices that contribute significantly to innovation performance

With the R-square values of 0.758 , this study has shown that TQM practices can be predictors of innovative performance. In other words, 75.8 per cent of the changes in innovation can be explained by the changes in TQM practices. The results have confirmed that people management, customer focus, and process management are the crucial TQM practices that affect innovation performance. Being customer-focused drives employees to improve the innovativeness of the company's products in order to meet customer demand and attain customer satisfaction. This result contradicts that of Projogo and Sohal [3], who maintained that a customer-oriented perspective hinders companies from being broadminded, restraining their ability to be innovative, and thereby preventing them from being productive and effective. On the other hand, process management is related significantly to quality performance. In this regard, improvement in innovation should be emphasised in terms of standardisation, process control, documentation, and efficiency. The goal of process management in manufacturing is to reduce the process variation by establishing a quality control in the production process.

Being customer-focused and having sound people and process management practices is advantageous to a manufacturing organisation in different ways. To ensure that customers are happy and satisfied, market surveys can be done by producing consumer prototypes to collect their opinions on demands and requirements. In terms of people management, having the right person for the right job increases the efficiency of the provided training, as well as organisational performance. A sound process management is one with efficient production line layout, which can produce high-quality products within a stipulated period, in order to meet customer demand. In addition, the remarkable impacts of TQM practices 
on innovative performance, which this study has identified, confirm the findings of previous research $[2,4,6,12-14,16,28-30]$.

\subsection{Implication of practice}

The results of this study have indicated clearly that there are several important factors for managerial workers and organisations to take into consideration regarding innovation performance. In agreement with Hoang et al. [12], who stated that quality is a key factor in the strategy to achieve business success, this study has shown TQM to be key to manufacturing organisations' innovation performance and, ultimately, their business success.

In spite of the results shown in this paper, leadership remains an important element of an organisation. Quality leadership has a central role in influencing the organisation to raise its potential to achieve targets. In other words, leadership with knowledge-intensive service also influences day-to-day innovative behaviour [31]. The result of quality leadership will be an increase in the innovative capabilities of the employees and the organisation. Another important element is strategic planning. With due attention paid to the development of organisational and individual strategic objectives and to the action plan, the correct strategic planning will increase an organisation's rate of business success.

The importance of customer focus, process management, and people management in innovation performance was discussed earlier. Customers' expectations are met better when the manufacturing company produces an innovative and high-quality product. For this reason, continuous improvement is a high priority, and it should be implemented in the organisation's systems and employees' behaviour [32].

As a dimension that is related significantly to quality performance, process management that emphasises standardisation, process control, documentation, and efficiency [33] reduces process variation; ultimately, it helps to reduce the occurrences of unnecessary costs such as re-work and waste costs. Finally, the successful implementation of people management in TQM may potentially reduce the amount of turnover. The cost of hiring new employees is often higher than retaining current employees. Thus, when turnover is reduced, the company will also be able to benefit through cost-saving. Furthermore, strategic human resource management is core to the success of TQM because it can inspire innovative output among employees. Human resource professionals should play their roles as strategic partners and develop policies that can spur innovation performance in the organisation. One of the most important human resource practices is the compensation system, which should be linked relevantly with performance output, driving employees to achieve greatness through innovation. Employees who are able to provide new and sound ideas that help organisations to break down the barriers that block success should be rewarded in a fair manner.

\subsection{Implications of the research}

The results of this study have contributed greatly to understanding the relationship between TQM practices and innovation performance for the manufacturing industry in Malaysia, and the practices that have contributed significantly to innovation performance. The results also suggest that further research should examine the impact of TQM practices on innovation performance in relation to other settings and other innovative elements such as marketing and servicing innovation. This is in line with the view that different sectors and industries may produce different results; but the identification and assessment of more radical innovations is possible through extensive study.

Second, though this study has confirmed the positive relationship between TQM practices and innovation performance, future research must examine how these two parameters are significantly similar to and different from each other. It is therefore suggested that the influence of decision-making at managerial level be compared with enhanced TQM practices that have led to better and sustained innovation performance. It is very likely that these decision paths differ greatly and depend on a number of contingencies. A good starting 
point for future research would be to examine the networks of these two constructs. The vast body of innovation performance research could benefit greatly from any insight resulting from this review.

The results of this study are also beneficial to the manufacturing industry in Malaysia because they can help organisations to identify the TQM practices that are crucial to their innovation performance.

Finally, this research has indicated that organisations that implement TQM practices have demonstrated improved product quality and innovation. Nevertheless, more related studies are needed in the future to broaden current understanding of the factors that contribute to improved innovation performances.

\section{ACKNOWLEDGEMENTS}

The authors wish to acknowledge the Malaysian Ministry of Higher Education and the University Teknologi Malaysia (Vot.4F349) for supporting and sponsoring this publication through its research grant.

\section{REFERENCES}

[1] Singh, P.J. \& Smith, A.J. 2004. Relationship between TQM and innovation: An empirical study. Journal of Manufacturing Technology Management, 15(5), pp. 394-401.

[2] Leavengood, S.A. 2011. Identifying best quality management practices for achieving quality and innovation performance in the forest products industry. Portland State University, Engineering Management. East Eisenhower Parkway: ProQuest LLC.

[3] Prajogo, D.I. \& Sohal, A.S. 2001. TQM and innovation: A literature review and research framework. Technovation, 21(9), pp. 539-558.

[4] Prajogo, D. \& Sohal, A. 2004. The multidimensionality of TQM pratices in determining quality and innovation performance: An empirical examination. Technovation, 24(6), pp. 443-453.

[5] Department of Statistics, Malaysia. 2013. National accounts: Gross Domestic Product (GDP). Retrieved

from http: / / www.statistics.gov.my/portal/index.php?option=com_content\&view=article\&tid=1589\&lte mid $=111 \&$ lang=en. Accessed on $1^{\text {st }}$ of September 2014.

[6] Lee, V.-H., Ooi, K.-B., Tan, B.-I. \& Chong, A.Y.-L. 2010. A structural analysis of the relationship between TQM practices and product innovation. Asian Journal of Technology Innovation, 18(1), pp. 73-96.

[7] Hovgaard, A. \& Hansen, E. 2004. Innovativeness in the forest product industry. Forest Products Journal, 54, pp. 26-33.

[8] Cormican, K. \& O'Sullivan, D. 2004. Auditing best practice for effective product innovation management. Technovation, 24(10), pp. 819-829.

[9] Adams, R., Bessant, J. \& Phelps, R. 2006. Innovation management measurement: A review. International Journal of Management Review, 8(10), pp. 21-47.

[10] Chong, V.K. \& Rundus, M.J. 2004. Total quality management, market competition and organizational performance. The British Accounting Review, 36, pp. 155-172.

[11] Terziovski, M. \& Samson, D. 1999. The link between total quality management practice and organization performance. International Journal of Quality \& Reliability Management, 163), pp. 226-237.

[12] Hoang, D.T., Igel, B. \& Laosirihongthong, T. 2006. The impact of total quality management on innovation - Findings from a developing country. International Journal of Quality \& Reliability Management, 23, pp. 1092-1117.

[13] Perdomo-Ortiz, J., Benito, J.G. \& Galenda, J. 2006. Total quality management as a forerunner of business innovation capability. Technovation, 26, pp. 1170-1185.

[14] Prajogo, D. \& Sohal, A. 2003. The relationship between TQM practices, quality performance, and innovation performance: An empirical examination. International Journal of Quality \& Reliability Management, 20(8), pp. 901-918.

[15] Pinho, J.C. 2008. TQM and performance in small medium enterprises: The mediating effect of customer orientation and innovation. International Journal of Quality \& Reliability Management, 25(3), pp. 256-275.

[16] Pekovic, S. \& Galia, F. 2009. From quality to innovation: Evidence from two French employer surveys. Technovation, 29, pp. 829-842. 
[17] Santos-Vijande, M. \& Alvarez-Gonzalez, L. 2007. Innovativeness and organizational innovation in total quality oriented firms: The moderating role of market turbulence. Technovation, 27(9), pp. 514-532.

[18] Abrunhosa, A. \& Moura E Sa, P. 2008. Are TQM principles supporting innovation in the Portuguese footwear industry? Technovation, 28(10), pp. 208-221.

[19] Ooi, K.-B., Lin, B., Teh, P. \& Chong, A.Y.-L. 2012, Does TQM support innovation performance in Malaysia's manufacturing industry? Journal of Business Economics and Management, 13(2), pp. 366-393.

[20] Zehir, C., Müceldili, B., Zehir, S. \& Ertosun, O.G. 2012, The mediating role of firm innovativeness on management leadership and performance relationship. Procedia - Social and Behavioral Sciences, 41, pp. 29-36.

[21] Lorente, A.R., Dewhurst, F. \& Dale, B.G. 1999. TQM and business innovation. European Journal of Innovation Management, 2 (1), pp. 12-19.

[22] Kim, W. \& Marbougne, R. 1999. Strategy, value innovation, and the knowledge economy. Sloan Management Review, 2, pp. 41-54.

[23] Slater, S. \& Narver, J. 1998. Customer-led and market-oriented: Let's not confuse the two. Strategic Management Journal, 19, pp. 1001-1006

[24] Wind, J. \& Mahajan, V. 1997. Issues and opportunities in new product development: An introduction to the special issue. Journal of Marketing Research, 34(1), pp. 1-12.

[25] Hair, J.F., Anderson, R.E., Tatham, R.L. \& Black, W.C. 1998. Multivariate data analysis. Englewood Cliffs, NJ: Prentice-Hall.

[26] Coakes, S.J., Steed, L.G. \& Ong, C. 2010. SPSS: Analysis without anguish. Version 17 for Windows. Vol. 17. Milton: John Wiley \& Sons Australia, Ltd.

[27] O’Brien, R.M. 2007. A caution regarding rules of thumb for variance inflation factors. Quality and Quantity, 41(5), pp. 673-690.

[28] Hung, R.Y., Lien, B.Y.-H., Yang, B., Wu, C.-M. \& Kuo, Y.-M. 2010. Impact of TQM and organizational learning on innovation performance in the high-tech industry. International Business Review, 20, pp. 213-225.

[29] Guimaraes, T. 2011. Industry clockspeed's impact on business innovation success factors. European Journal of Innovation Management, 14(3), pp. 322-344.

[30] Feng, J., Projogo, D.I., Tan, K.C. \& Sohal, A.S. 2006. The impact of TQM practices on performance: A comparative study between Australian and Singaporean organizations. European Journal of Innovation Management, 9(3), pp. 269-278.

[31] Jong, J.P. \& Den Hartog, D.N. 2007. How leaders influence employees' innovative behaviour. European Journal of Innovation Management, 10(1), pp. 41-64.

[32] Daghfous, A. \& Barkhi, R. 2009. The strategic management of information technology in UAE hotels: An exploratory study of TQM, SCM, and CRM implementations. Technovation, 29, pp. 588595.

[33] Flynn, B.B., Schroeder, R.G. \& Sakakibara, S. 1995. The impact of quality management practices on performance and competitive advantage. Decision Science, 26(5), pp. 659-691. 